\title{
Environmental asbestos contamination in an abandoned chryso- tile mining site: the example of Val Malenco (central Alps, north- ern Italy)
}

University of Milano-Bicocca, Department of Earth and Environmental Sciences, Piazza della Scienza 1-4, 20126 Milano (MI) - Italy;

*Corresponding author, E-mail: alessandro.cavallo@unimib.it

(Received: January 31, 2020; Revised accepted: March 22, 2020)

https://doi.org/10.18814/epiiugs/2020/0200s01

The Valmalenco area (central Alps, northern Italy) is well-known for the widespread mining and quarrying activities. Serpentinites are extracted and processed as valuable dimension stone in open-cast quarries, and a big underground mine provides talc as industrial mineral. The presence of long-fiber chrysotile veins, especially in the eastern part of the valley, gave rise in the past to widespread mining activity, particularly between the end of the XIX century and 1975, leaving huge amounts of mining waste and tailings. In recent times, part of the tailings have been stabilized and reclaimed, covered with soil and planted. Extensive sampling of mine tailings, soils and alluvial sediments was performed, to detect asbestos contamination (XRPD, SEMEDS, TEM). Airborne asbestos was measured by environmental monitoring on polycarbonate filters (SEM and TEM), at the abandoned mines and at the closest centers. Huge amounts of chrysotile are still present in mine tailings (up to $20 \mathrm{wt} \%$ ), whereas soils and sediments were mostly below the 1000 ppm threshold; chrysotile is widespread almost in every part of the valley. Small amounts $(<400 \mathrm{ppm})$ of asbestiform tremolite were detected. Airborne asbestos was below the PEL of 2ffll for living environments, with some peaks at mine dumps and close to active serpentine quarries. This preliminary study provides useful tips and effective technical measures for risk reduction in the extractive context.

\section{Introduction}

Naturally Occurring Asbestos (NOA) is a general all-encompassing name given to asbestos minerals found in-place in their natural state, in rock masses (especially ultramafic and mafic rocks), soils and sediments. Asbestos includes chrysotile (serpentine asbestos) and the asbestiform amphibole varieties of actinolite, amosite (grunerite), anthophyllite, crocidolite (riebeckite), and tremolite (Alleman and
Mossman, 1997; Gualtieri, 2012; Ballirano et al., 2017; EEC, 2018). NOA has raised concern worldwide since the appearance of evidences in the scientific literature of increased risk of malignant mesothelioma in the population exposed to airborne asbestos released from natural occurrences (Petriglieri et al., 2020). It has been scientifically proven that the inhalation of asbestos fibers can cause severe illnesses, like malignant mesothelioma and lung cancer: all these minerals are included by the International Agency for Research on Cancer (IARC, 2012) in Group 1 "substance carcinogenic to humans". In addition to regulated asbestos, there is a wide range of asbestiform minerals which have been classified as carcinogenic (e.g., erionite and fluoroedenite, Gualtieri et al., 2017), or are under investigation (e.g., asbestiform antigorite, Petriglieri et al., 2020). Without appropriate knowledge and engineering controls, NOA deposits may pose a potential health hazard if these rocks are exposed to natural erosion or to human activities creating dust; recently, innovative analytical approaches have been developed to identify NOA (Bloise and Miriello, 2018; Bloise et al., 2020; Petriglieri et al., 2020). Italy is an excellent example for NOA, due to the abundance of ultramafic rocks and ophiolites both in the Alps and Apennines (Bloise et al., 2016; Bloise et al., 2017; Bloise et al., 2019; Belluso et al., 2020), as well as mining and quarrying activities: Italy hosted till 1992 the biggest European chrysotile mine in Balangero, Piedmont. Good quality long fiber chrysotile was also produced in Valmalenco (central Alps): this area is in the Lombardy region (northern Italy), about a hundred $\mathrm{km}$ north of Milan and close to the Italy-Switzerland border (Fig. 1). It is one of the most important side valleys of Valtellina, and it covers an area of about $315 \mathrm{~km}^{2}$ and a length of almost $25 \mathrm{~km}$. Due to the peculiar geology, characterized by large outcrops of ultramafic rocks, mining and quarrying activities represent an important economic resource for the valley: there are about 15 active serpentinite quarries (green "marble") and one steatite mine (impure talc for rubber and plastic industry). In the past, long-fiber chrysotile asbestos was extracted in underground mines, leaving huge amounts of debris and mine wastes. This paper focusses on the presence of asbestos and other mineral fibers in mine tailings, soils, alluvial sediments and in the air surrounding the abandoned mining district. 


\section{Geological Framework}

The geological and structural set-up is represented in Valmalenco by the following nappes which lie superimposed in the following order, from the deepest to the upper: Suretta, Monte Forno and Malenco (upper Penninic), Margna, Sella, Bernina, Campo and Grosina-Tonale nappes (lower Austroalpine, Trommsdorff et al., 2005 and references therein). The nappe pile was crosscut by Oligocene magmatic intrusions: the Masino-Bregaglia and the small Triangia plutons. The three main geological units that characterize the boundary between the Penninic and Austroalpine domains are:

1. the Margna nappe, consisting of a crystalline basement and a Mesozoic cover;

2. the Malenco nappe, an ultramafic massif with a pre-oceanic granulitic basement and Jurassic ophicarbonates;

3. the ophiolitic Monte Forno nappe, consisting of Jurassic oceanic sediments, pillow lavas, volcanoclastic rocks and basic dikes which marginally crosscut the Malenco nappe (Trommsdorff and Connolly, 1996).

The Malenco nappe (Fig. 1) has a considerable extension (about $170 \mathrm{~km}^{2}$ ), with a thickness between 1 and $2 \mathrm{~km}$, interposed between the Margna (lower Austroalpine) and the Suretta nappes (upper Penninic), both consisting of a pre-Mesozoic metamorphic basement and a Mesozoic cover. It is composed mainly of ultramafic rocks: the lower portion consists of schistose serpentinites and serpentinized peridotites, and subordinately spinel lherzolites, garnet clinopyroxenites, spinel websterites, dunites and harzburgites (Münterer and Hermann, 1996). The predominant rock type is a schistose serpentinite with non-pseudomorphic texture, and consist of antigorite, olivine, diopside and minor magnetite and chlorite. Locally, these rocks are cut by talc and chrysotile lodes and veins, related to the late phases of the orogenic event, at low to very low temperature and high-fluid activity recrystallization conditions (Ulmer and Trommsdorff, 1995). The upper portion consists of continental crust rocks in granulite facies, essentially garnet-bearing gneisses with minor granitoids, and subordinate Ca-silicate mar-

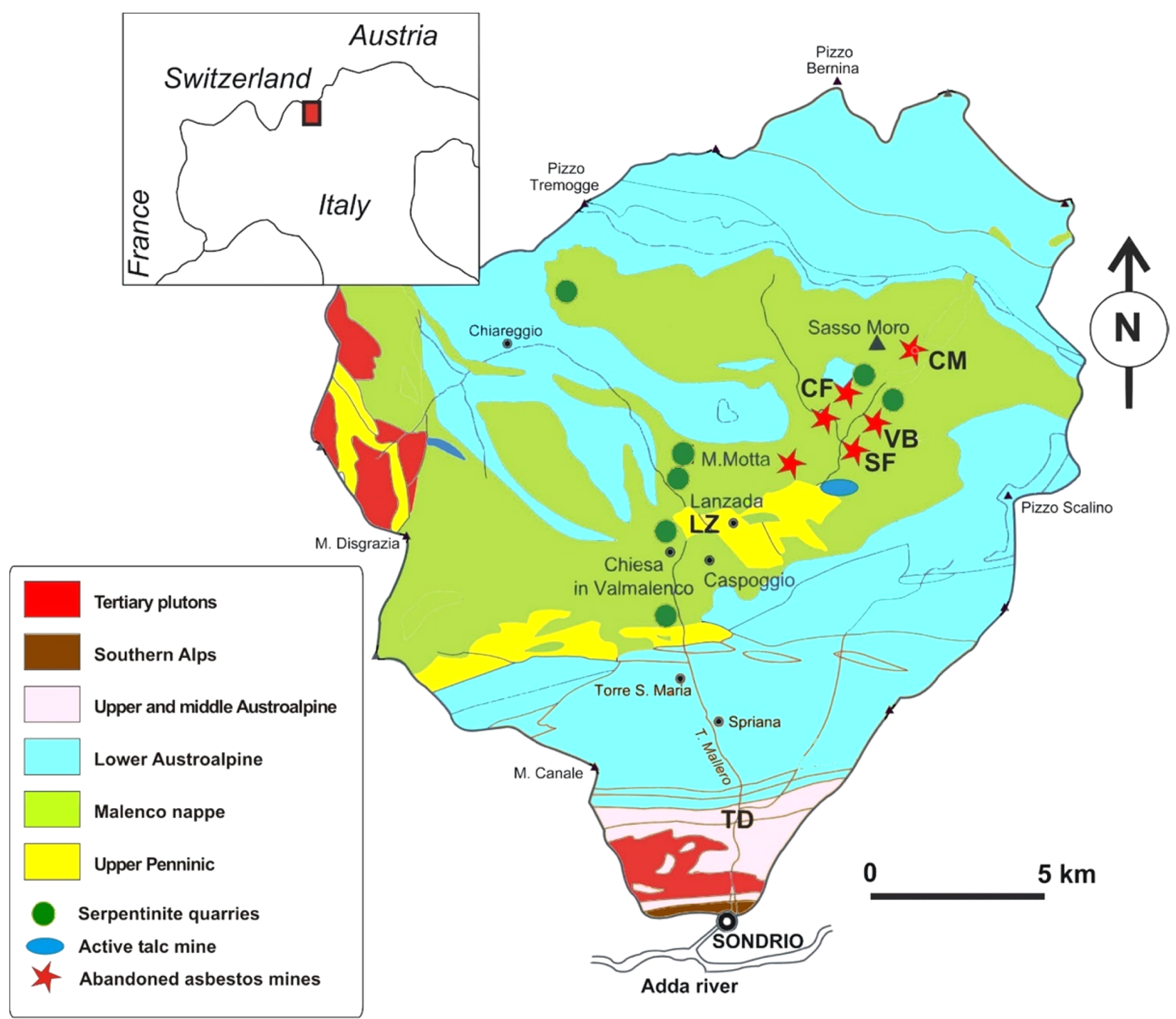

Figure 1. Simplified geological sketch map of the Valmalenco area, indicating the main quarrying and mining districts and the sampling locations (CM, CF, VB, SF, LZ and TD). 
bles. The ultramafites and the upper granulites are "welded" by the Permian Fedoz gabbro, intruded at the transition between the mantle and the lower continental crust (Münterer and Hermann, 1996). The Malenco unit therefore represents an undisturbed upper mantle - lower continental crust section, the crust-mantle transition in the Permian, the pre-Alpine lithosphere of the Adria plate (Münterer et al., 2000).

\section{Mining and Quarrying Activity}

The peculiar geology and the overall good quality of the rock mass gave rise to widespread quarrying and mining activities (Fig. 1). At present time, the most important extractive activity is represented by serpentinite extraction: 22 different enterprises (more than 150 workers involved) operate in the quarrying and/or processing of serpentinites with various textures, schistose to massive, and color shades; the finished products are used all over the world and are known with many commercial names (e.g., "Serpentinoscisto Valmalenco", "Verde Vittoria"). The total amount extracted in the quarries is estimated around $195 \mathrm{kt} / \mathrm{yr}$., with a waste production (irregular blocks, rock chips, processing sludge) around $128 \mathrm{kt} / \mathrm{yr}$. (Cavallo, 2018). The serpentinite was extracted at least since the 11th century, exported to Switzerland before the 18th century and abundantly used in Sondrio and Valtellina since the 14th century; it is an appreciated dimension stone because of its green color and the excellent technical properties (e.g., slabs for roof covering). Steatite (impure talc, with small amounts of serpentine, chlorite and magnesite) is also actively mined in the area: it occurs in metric, sub-vertical lodes within the serpentinites and/or at the contact with dolomitic marbles. The extraction occurs in a huge underground mine (Brusada-Ponticelli) by the Italian IMI Fabi company, the third largest producer of talc in the world. Steatite is mainly used as industrial mineral, as a filler for plastic, rubber, paper and paints. The eastern part of the area (Lanterna valley) is characterized by abundant chrysotile asbestos veins, linked to an important ENE-WSW striking fracture system. It is a long-fiber chrysotile, occurring in subvertical cross-fiber and slip-fiber lodes and veins, with thickness between some $\mathrm{mm}$ up to $1 \mathrm{~m}$. The abundance and the good quality of this longfiber chrysotile asbestos gave rise to widespread mining, particularly between the end of the 19th century and 1975 (Bedognè et al., 1993) and was used mainly for weaving tablecloths or for candle wicks, due to its excellent spinnability. At the beginning of the 19th century the noblewoman Candida Lena Perpenti from Chiavenna managed to obtain asbestos threads useful for the textile industry. This led to an important mining activity: in 1830 there are historical records of the extraction of about 6 tons of asbestos, and 25 tons in 1870, with more than 150 miners employed; in this period the extraction of asbestos took place with the contribution of French technicians (Bedognè et al., 1993). On the other hand, chrysotile asbestos from Valmalenco was shown at the World Exhibitions in Paris (1854), as well as in Milan (1861). A big boost to mining activity occurred during World War II and immediately after, with annual production up to 670 tons and more than 400 workers employed, until mining ended completely in 1975, leaving huge amounts of mining waste and tailings (Fig. 2). The best-known places for asbestos mining were Campo Franscia, Alpe Lagazzuolo, Sferlun, Campo Moro, Valbrutta, Monte Cuveglia, and Alpe Cambr. Since the end of the extraction activity, only a small part of the abandoned mining sites has been reclaimed: in particular, since 2005 part of the mine dumps closest to the main roads have been partly terraced and covered with about $0.5 \mathrm{~m}$ of soil, subsequently planted with grass and shrubs (Fig. 2). In most of the remaining abandoned mines, the main problem is represented by large debris and tailing dumps, with stability problems related to the steepness and heterogeneity of the waste material (ranging from blocks to sand). Since 2005 many airborne particulate control campaigns have been carried out in the serpentine quarries and in the stone processing facilities (Cattaneo et al., 2012; Cavallo and Rimoldi, 2013), but there are no data regarding the abandoned asbestos mines, which in some cases are very close or even inside the current active serpentine quarries (Fig. 3). The almost
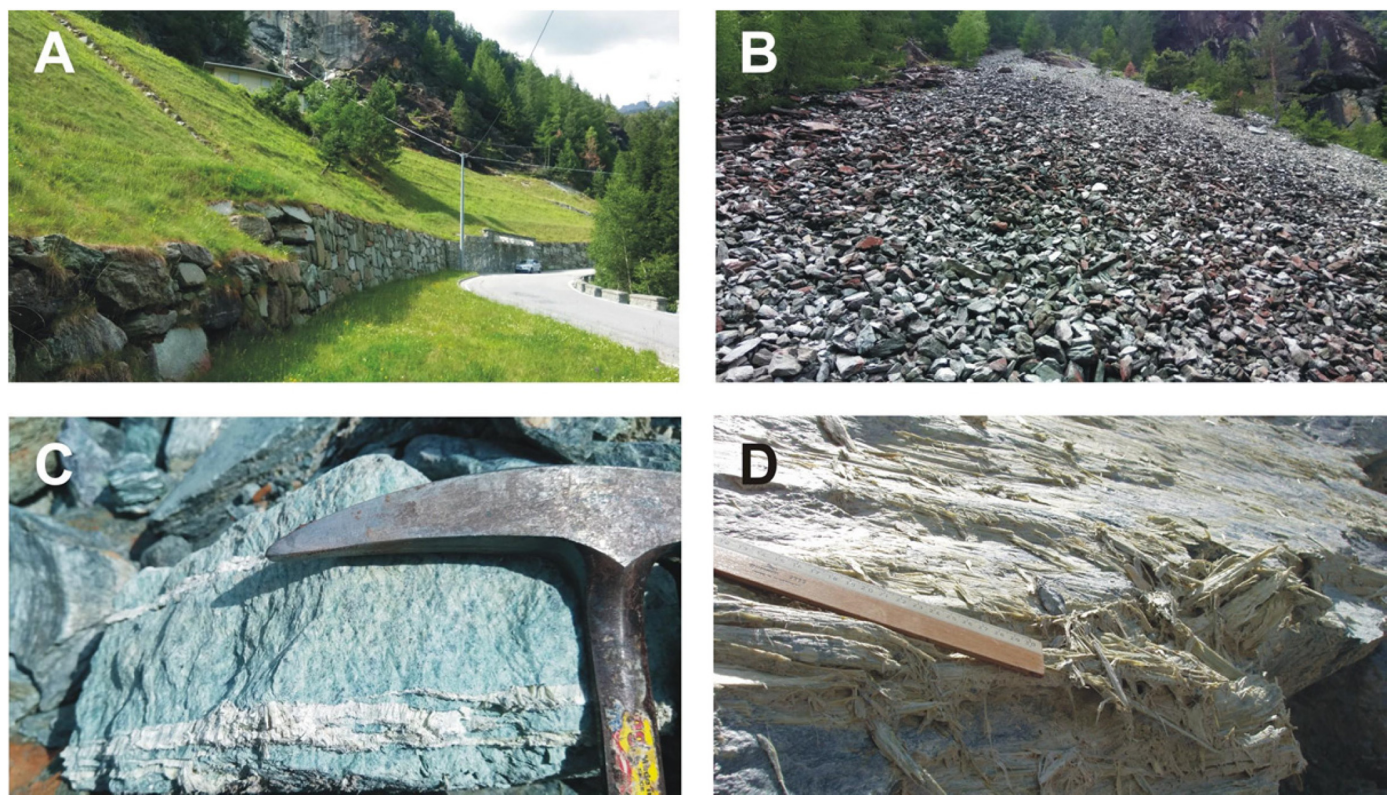

Figure 2. 2A) remediated mine dump in Valbrutta (VB); $2 B$ ) tailings fan of the Sferlun (SF) mine; 2C) cross-fiber chrysotile veins in mine debris, Campo Franscia (CF); 2D) slip-fiber chrysotile veins in Campo Moro (CM) locality. 


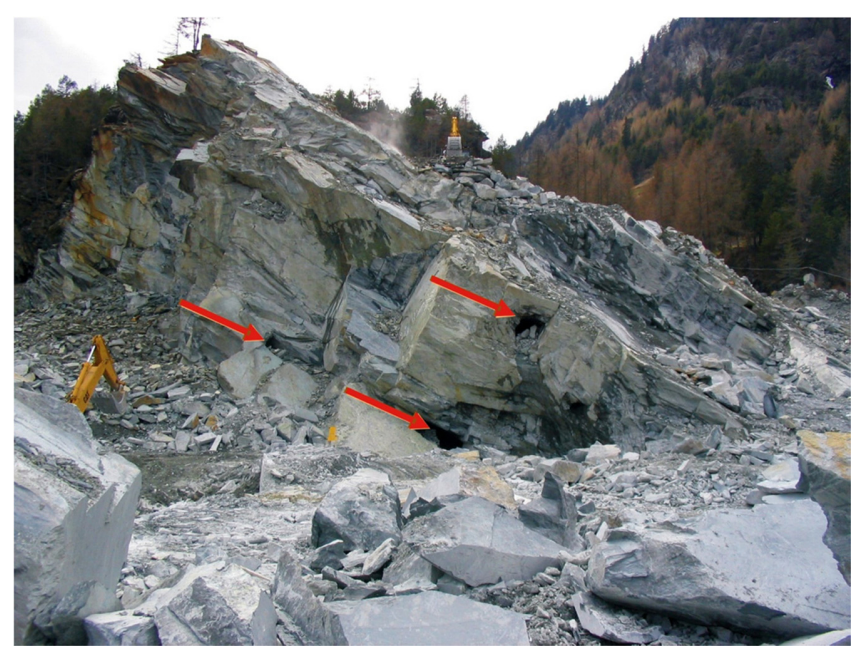

Figure 3. Active serpentinite quarry crosscutting abandoned mine shafts (red arrows), Campo Franscia (CF).

total lack of information on the potential pollution in mine wastes, soils and alluvial sediments therefore made a preliminary assessment for asbestos contamination necessary. In Italy the extraction, importation, exportation, trading and production of asbestos was definitely banned with law 257-1992. The guidelines for detection and quantification of asbestos in artificial and natural materials (e.g., rocks and soils) are described in the Italian laws D.M. 06.09.94 and D.M. 14.05.96 (Italian Ministry of Health, 1994 and 1996) and in their respective updates in the D.Lgs. 152/06 (Italian Ministry of Environment, 2006). The contamination threshold for "massive" materials is fixed at $1000 \mathrm{ppm}$. The World Health Organization (WHO, 1997) fixed a limit value of $1 \mathrm{ff} / 1$ for air quality protection; the Italian law states that concentrations of $2 \mathrm{ff} / \mathrm{l}$ detected through scanning electron microscopy (SEM) must be considered a sign of pollution.

\section{Materials and Methods}

Four different abandoned mining sites were investigated: Campo Franscia (CF), Valbrutta (VB), Campo Moro (CM) and Sferlun (SF). Alluvial sediments were collected in Valbrutta (VB), Lanzada (LZ) and Tornad (TD) localities, to evaluate the dispersion of asbestos fibers in sediments along the valley. Sampling of mine tailings, soils and stream sediments was carried out from 2008 to 2018, and airborne asbestos concentrations have been monitored at least once a year since 2012. A total of 35 mine tailings, 30 soil and 25 stream sediment samples were collected and characterized for bulk mineralogy and asbestos concentration. The evaluation and quantification of asbestos contamination in natural samples requires special care: a representative sample (considering grain size, planar anisotropies, veins and vein thickness), an accurate sample preparation (avoiding excessive grinding and fiber "destruction"), and a correct approach for the discrimination between asbestiform minerals and non-asbestiform or pseudo-fibrous varieties (lamellar serpentine fragments that fall into the WHO fiber definition, acicular amphiboles). The bulk mineralogy (limit of detection-LOD between 0.5 and 2 wt. $\%$, depending on crystallinity) was determined by X-ray powder diffraction (XRPD) using a Bragg-Brentano $\theta-\theta$
PANalytical X'Pert PRO PW3040/60 diffractometer with Ni-filtered $\mathrm{Cu} \mathrm{K} \alpha$ radiation at $40 \mathrm{kV}$ and $40 \mathrm{~mA}, 1 / 2^{\circ}$ divergence and receiving slits, and step scan of $0.02^{\circ} 2 \theta$, in the $3-70^{\circ} 2 \theta$ range. Quantitative phase analysis was carried out running the FULLPAT software (Chipera and Bish, 2002). Quantitative asbestos determination was carried out by SEM-EDS (Vega TS Tescan 5163 XM SEM - EDAX Genesis 400 EDX energy dispersive $\mathrm{x}$-ray spectrometry system) following specific technical criteria for naturally occurring asbestos - NOA (Italian D.Lgs 152/06, NIOSH, 2011; Gualtieri et al., 2014; Belluso et al., 2017; Gualtieri et al., 2018).

Airborne asbestos was analyzed mainly in the summer season, in 75 environmental air samples (65 SEM-EDS and 10 TEM), collected from the center of mine dumps, at mine borders, and at the closest villages. Environmental sampling was carried out with a high flow portable pump (ZB2, Zambelli), placing the filter at breathing zone height $(160 \mathrm{~cm}$ above floor level), at a fow rate of $51 \mathrm{~min}^{-1}$; the volume sampled was between 1500 and 32001 . SEM-EDS analysis was performed according to national legislation (Ministerial Decree 257, 1994) and ISO Method 14966 (2002), and TEM analysis [Philips CM120 transmission electron microscope equipped with an Oxford INCA energy dispersive $\mathrm{x}$-ray spectrometry system (EDS) and selected area electron diffraction (SAED) capability] according to NIOSH Method 7402 (1994). The fiber definition criteria are those cited in the references above (length $>5 \mu \mathrm{m}$, diameter $<3 \mu \mathrm{m}$ and aspect ratio $>3: 1$ ). Polycarbonate filters (Osmonics $25 \mathrm{~mm}$ diameter, porosity $0.8 \mathrm{~mm}$ ) were used for SEM-EDS and TEM analyses; the filter area to be examined was calculated for each filter in order to obtain a LOD of $0.1 \mathrm{ff} / 1$.

\section{Results}

\section{Mine Wastes and Tailings, Soils and Stream Sediments}

The bulk mineralogy of the samples determined by XRPD is reported in Table 1. Mine waste and tailings are extremely rich ( $\geq 70 \mathrm{wt} . \%)$ in antigorite, with minor amounts of olivine, chlorite, clinopyroxene and magnetite (not reported in Table 1). On the other hand, soils and stream sediments contain appreciable amounts of quartz, feldspars and carbonates (calcite and dolomite). Smaller amounts or traces of amphiboles were detected in almost all samples. The discrimination among serpentine polymorphs (e.g., antigorite and chrysotile) by XRPD was not performed, as this would require the Rietveld method (Rietveld, 1969), providing reliable results only for high grade samples (Gualtieri et al., 2014). Asbestos content of "massive" samples by SEM-EDS is reported in Table 2. Mine waste and tailings are highly contaminated by chrysotile (always $>1000$ ppm, e.g., Fig. 4), especially in CF and VB (up to $>20$ wt.\%), with generally higher amounts in the fine fraction $(<2 \mathrm{~mm})$. Asbestiform tremolite (e.g., Fig. 4) was detected in small amounts $(\leq 300$ ppm), especially in VB, as well as minor amounts of non-asbestiform tremolite. All soil samples show appreciable amounts of chrysotile, with higher concentrations in $\mathrm{CF}$, frequently exceeding the 1000 ppm threshold; also, soil used for reclamation (e.g., in VB) contains fair amounts of chrysotile, generally $<800 \mathrm{ppm}$. Chrysotile and small amounts of asbestiform tremolite were found in almost all stream sediments samples, with higher values close to the abandoned mines in the eastern part (VB) of the valley, but also in the lower part (TD). 
Table 1. bulk mineralogy of mine tailings, soil and alluvial sediment samples by XRPD. Limit of detection (LOD) is approximately 0.5 - 1 wt.\%. ++ = very abundant (> 25 wt.\%); + = abundant (10 - 25 wt.\%); $O=$ fair amounts (2-10 wt.\%); - traces ( $\leq 2$ wt.\%). Srp = serpentine; Qtz= quartz; Pl + Kfs

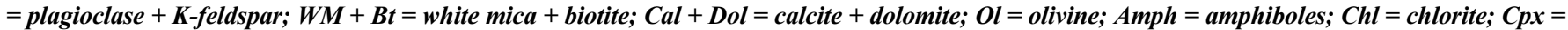
clinopyroxene (diopside); Mag = magnetite. Abbreviations according to Whitney and Evans, 2010

\begin{tabular}{|c|c|c|c|c|c|c|c|c|c|c|}
\hline Material & Srp & Qtz & $\mathrm{Pl}+\mathrm{Kfs}$ & $\mathrm{WM}+\mathrm{Bt}$ & Cal + Dol & $\mathrm{Ol}$ & Amph & Chl & $\mathrm{Cpx}$ & Mag \\
\hline $\mathrm{CF}$, mine tailings & ++ & $<\mathrm{LOD}$ & $<\mathrm{LOD}$ & $<\mathrm{LOD}$ & - & + & $<\mathrm{LOD}$ & - & $\mathrm{O}$ & - \\
\hline $\mathrm{CF}$, soil at mine border & ++ & $\mathrm{O}$ & $\mathrm{O}$ & $\mathrm{O}$ & - & - & - & $\mathrm{O}$ & - & - \\
\hline $\mathrm{VB}$, mine tailings & ++ & $<\mathrm{LOD}$ & $<$ LOD & $<\mathrm{LOD}$ & - & $\mathrm{O}$ & - & $\mathrm{O}$ & $\mathrm{O}$ & - \\
\hline VB, soil at mine border & ++ & $\mathrm{O}$ & $\mathrm{O}$ & $\mathrm{O}$ & $\mathrm{O}$ & - & - & $\mathrm{O}$ & - & - \\
\hline CM, mine tailings & ++ & $<\mathrm{LOD}$ & - & $<\mathrm{LOD}$ & - & - & - & - & $\mathrm{O} /-$ & - \\
\hline SF, mine tailings & ++ & - & $<\mathrm{LOD}$ & - & - & $\mathrm{O}$ & $<\mathrm{LOD}$ & - & $\mathrm{O} /-$ & - \\
\hline VB, alluvial sediments & ++ & + & + & $\mathrm{O}$ & $\mathrm{O}$ & $\mathrm{O}$ & $\mathrm{O}$ & $\mathrm{O}$ & - & -- \\
\hline LZ, alluvial sediments & + & + & + & $\mathrm{O}$ & $\mathrm{O}$ & - & $\mathrm{O}$ & $\mathrm{O}$ & - & -- \\
\hline TD, alluvial sediments & + & + & + & + & $\mathrm{O}$ & - & $\mathrm{O}$ & $\mathrm{O}$ & $-/--$ & -- \\
\hline
\end{tabular}

Table 2. asbestos concentrations (chrysotile and asbestiform tremolite, mean and range) in mine tailings, soil and alluvial sediment samples by SEMEDS. Limit of detection (LOD) is approximately 50 ppm. *For chrysotile in mine waste and tailings the value is given in wt.\%

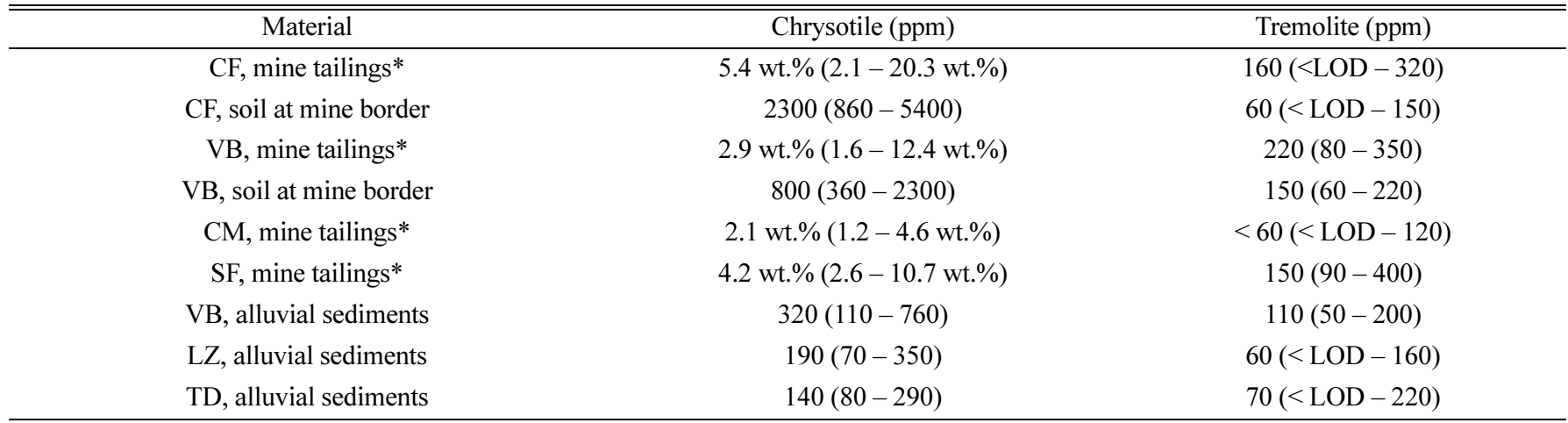
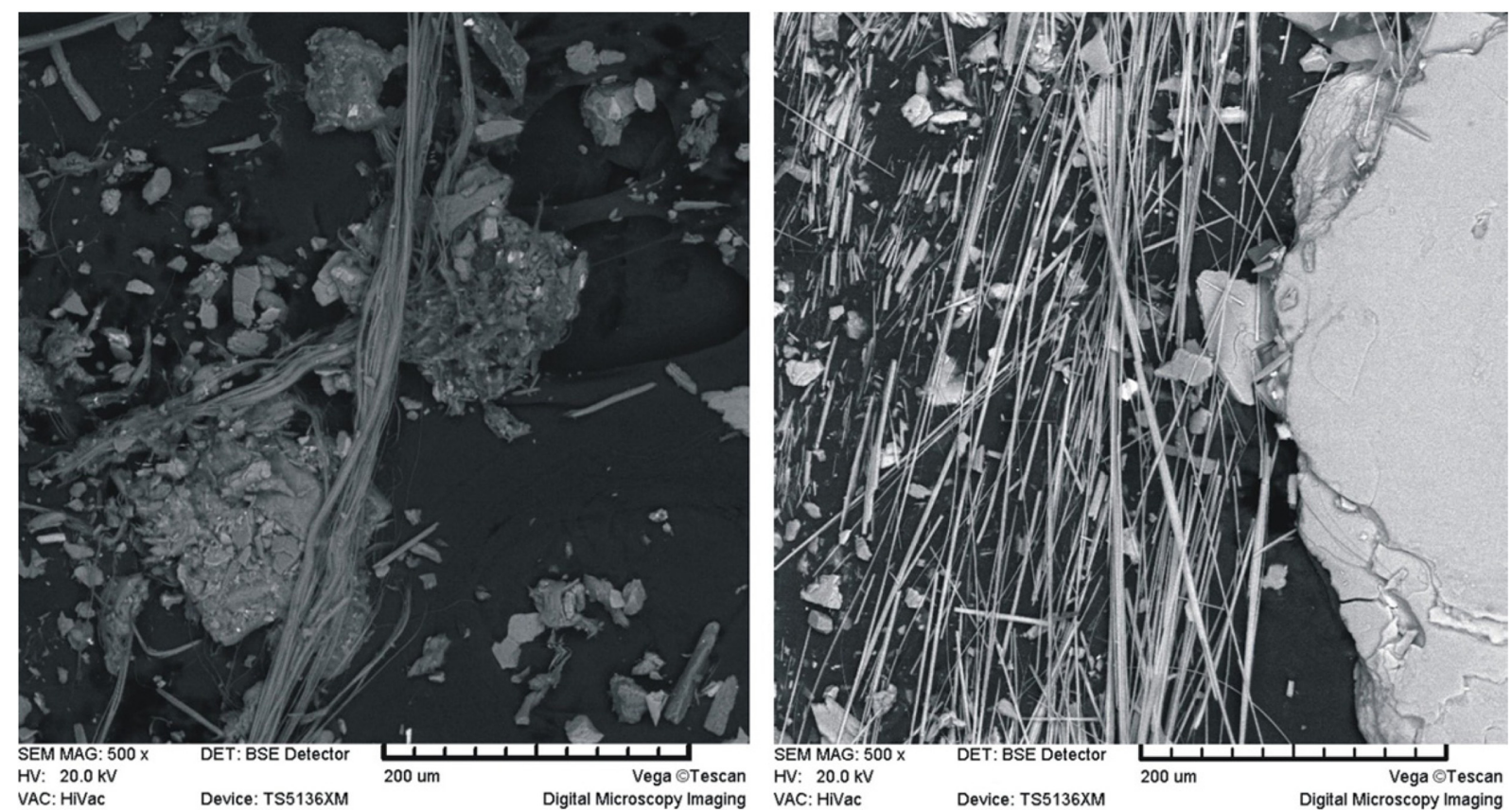

Figure 4. SEM micrographs showing abundant chrysotile fiber bundles (on the left) and asbestiform tremolite (on the right).

\section{Airborne Asbestos}

The analysis of airborne asbestos (Table 3) highlighted a complex environment, especially were the abandoned mines are close to active quarries (VB and CF). Due to the abundance of lamellar antigorite with high aspect ratio (up to 20:1), some filters were loaded with pseudo-fibrous antigorite splinters, falling into the WHO fiber definition. The discrimination between chrysotile and pseudo-fibrous 
Table 3. airborne asbestos exposure values (chrysotile and asbestiform tremolite), environmental sampling (ffl). Limit of detection (LOD) is approximately $0.1 \mathrm{ffl} /$

\begin{tabular}{ccc}
\hline \hline Sampling position & Chrysotile (ff/l, mean and range) & Asbestiform tremolite (ff/l, mean and range) \\
\hline CF, mine dump & $4.1(0.5-22.3)$ & $<0.1(<$ LOD -0.1$)$ \\
CF, mine border & $2.1(0.2-5.7)$ & $<0.1(<$ LOD -0.1$)$ \\
VB, mine dump & $3.2(0.4-12.2)$ & $0.1(<$ LOD -0.3$)$ \\
VB, mine border & $0.4(0.1-1.2)$ & $<$ LOD \\
CM, mine dump & $0.2(0.1-0.5)$ & $<$ LOD \\
SF, mine dump & $1.7(0.4-6.8)$ & $<$ LOD \\
LZ, close to city center & $0.1(<\mathrm{LOD}-0.5)$ & $<$ LOD \\
TD, close to Mallero river & $<0.1(<\mathrm{LOD}-0.2)$ & $<$ LOD \\
\hline
\end{tabular}
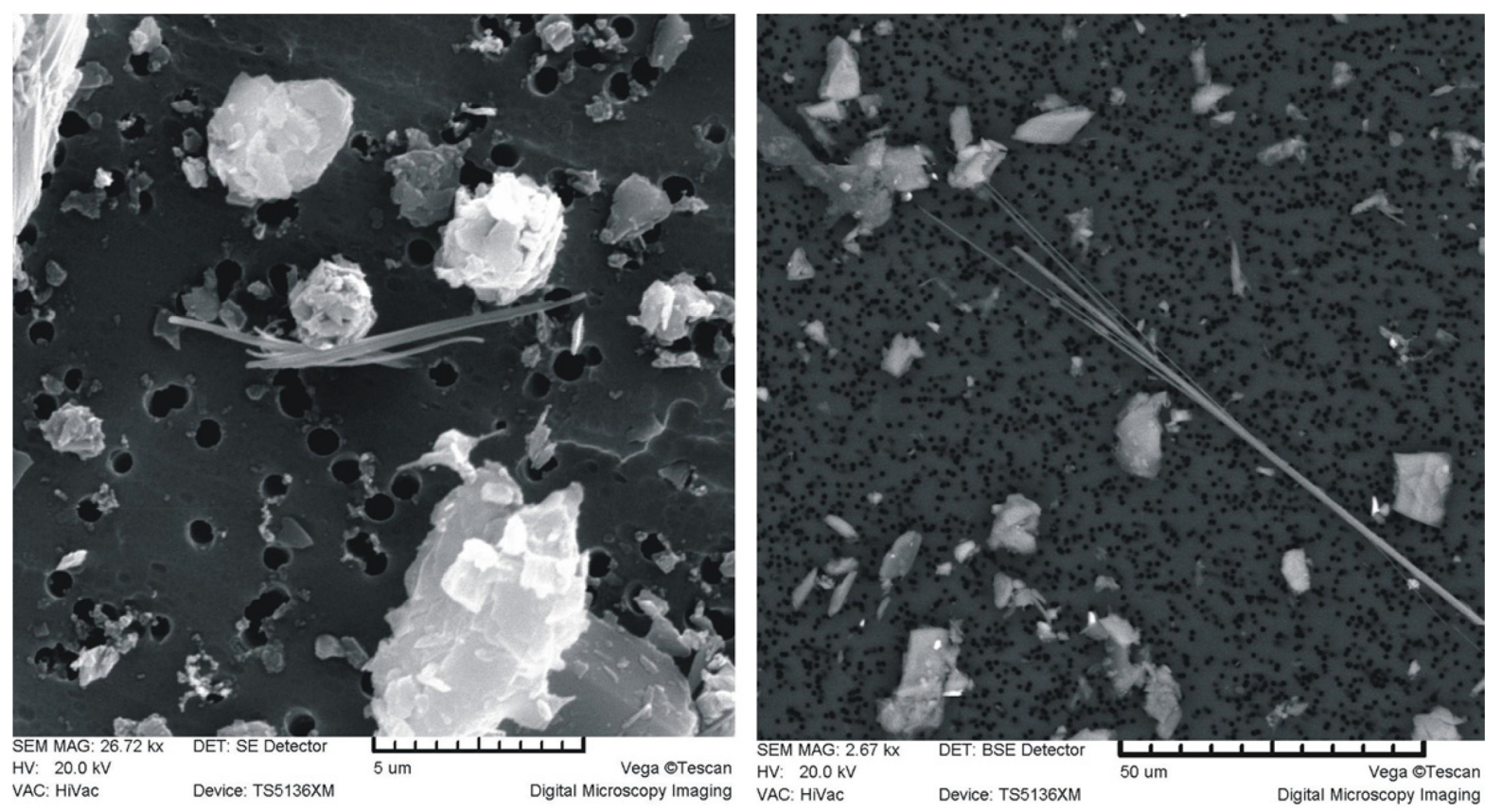

Figure 5. SEM micrographs of polycarbonate filters with airborne asbestos fibers. Chrysotile (on the left) and asbestiform tremolite (on the right).

lamellar serpentine was based both on morphological and dimensional criteria (Cattaneo et al., 2012; Cavallo and Rimoldi, 2013; Belluso et al., 2017). Chrysotile was found in form of isolated fibrils with a length between 6.5 and $25 \mu \mathrm{m}$, or as fiber bundles; the mean diameter of chrysotile fibrils and chrysotile bundles was $0.06 \mu \mathrm{m}$ $(0.03-0.16)$ and $0.80 \mu \mathrm{m}(0.08-2.6)$ respectively. In some cases (especially $\mathrm{CF}$ ) chrysotile micro-fibrils (length $<5 \mu \mathrm{m}$, not countable according to WHO criteria) were detected, probably linked to the active quarrying activities and the fine comminution by blasting and diamond wire cutting. TEM showed always good agreement with SEM data. Asbestiform tremolite was observed only in CF and VB (Fig. 5), probably indicating a tremolite pollution source (ophicarbonates and/or talc lodes); all previous studies did not detect amphibole asbestos (Cattaneo et al., 2012; Cavallo and Rimoldi, 2013). Values measured at mine borders were always lower than those at mine dump, whereas values at nearest town (LZ and TD, 5 and $10 \mathrm{~km}$ from the abandoned mines respectively) were well below the environmental exposure limit $(<2 \mathrm{ff} / \mathrm{l})$, indicating a scarce fiber dispersion.

\section{Discussion}

Mine debris and tailings are exceptionally rich in chrysotile, because only the best quality long fiber asbestos was extracted and separated, discarding the lesser quality one. One of the main problems is represented by the geotechnical stability of some very steep mine dumps (e.g., SF, Fig. 2B), prone to landslides, but the difficult access makes stabilization works almost impossible. Soils contain appreciable amounts of asbestos, but these are probably "natural background" values, as it is difficult to correlate them with mining, which has not physically interfered with the surrounding soils. The alluvial sediments are the result of the natural sampling of the debris from the outcropping lithologies, and the values found, although all below the 1000 ppm threshold, suggest to pay attention to their possible use as aggregate (sand, gravel), especially the finer fractions (sand and silt). Due to the huge outcrops of serpentinites, the active quarries and the abandoned mines, the presence of chrysotile was expected, whereas traces of asbestiform tremolite were a disturbing and widespread surprise: it is not reported in literature, and is probably linked to ophicarbonates and/or talc 
veins, which occur is some localities (e.g., VB). The current mining and quarrying activities for talc and serpentinite represent an important source of income for the valley, but the widespread presence of chrysotile veins, as well as the proximity of the mine dumps, require attention, especially not to interfere with the stability of the latter.

\section{Conclusions}

This preliminary study evidenced a strong asbestos contamination of mine tailings, in some cases even more than $20 \mathrm{wt} . \%$. Most of the tailings are completely exposed to atmospheric agents, with a marked risk of dispersion during meteorological events. Mine dumps are also very steep, with consequent risk of landslides. The remediation involved only a small part of the dumps, but the good resistance and durability suggests the extension to the remaining parts; covering the tailings with agricultural soil and subsequent planting can certainly reduce the possibility of fibers release into the environment. The volume of tailings should be evaluated with other approaches (e.g., geophysics), for an estimate of their volume. The proximity of the abandoned mines to the active serpentine quarries (VB and CF) is particularly critical, both for the presence of asbestos in the rock mass and for the excavation activities, which can release the fibers in the air. Any further extension of the quarries requires detailed geological studies, aimed at reducing the possibility of intercepting asbestos veins. The airborne fiber data are relatively encouraging, with values that decrease rapidly moving away from mining sites. However, the ubiquitous presence of asbestos in soils and sediments requires special attention, because it might lead to worrying concentrations of airborne fibers during excavation activities, which therefore require preventive measures. A further criticality is represented by the presence of traces of asbestiform tremolite, which is not reported in the literature, and whose source is to be sought with in-depth geological and petrographic studies.

\section{References}

Alleman, J.E., and Mossman, B.T., 1997, Asbestos revisited. Scientific American, v. 277, pp. 54-57.

Ballirano, P., Bloise, A., Gualtieri, A.F., Lezzerini, M., Pacella, A., Perchiazzi, N., Dogan, M., and Dogan, A.U., 2017, The crystal structure of mineral fibers. In Gualtieri, A.F. (Eds.), Mineral Fibres: Crystal Chemistry, Chemical - physical properties, Biological Interaction and Toxicity, EMU Notes in Mineralogy, 18. European Mineralogical Union and Mineralogical Society of Great Britain and Ireland, London, pp. 17-53.

Bedognè, F., Montrasio, A. and Sciesa, E., 1993, I minerali della provincia di Sondrio - Valmalenco, Stampa Bettini, Sondrio, 275 p.

Belluso, E., Baronnet, A., and Capella, S., 2020, Naturally Occurring Asbestiform Minerals in Italian Western Alps and in Other Italian Sites. Environmental and Engineering Geoscience, v. 26, pp. 39-46.

Belluso, E., Cavallo, A., and Haltermann, D., 2017, Crystal habit of mineral fibers. In Gualtieri, A.F. (Eds.), Mineral Fibres: Crystal Chemistry, Chemical - physical properties, Biological Interaction and Toxicity, EMU Notes in Mineralogy, 18. European Mineralogical Union and Mineralogical Society of Great Britain and Ireland, London, pp. 65-110.

Bloise, A., and Miriello, D., 2018, Multi-analytical approach for identifying asbestos minerals in situ. Geosciences, v. 8, Article number 133.

Bloise, A., Catalano, M., Critelli, T., Apollaro, C., and Miriello, D., 2017, Naturally occurring asbestos: Potential for human exposure, San Seve- rino Lucano (Basilicata, Southern Italy). Environmental Earth Sciences, v. 76, pp. 648-660.

Bloise, A., Punturo, R., Catalano, M., Miriello, D., and Cirrincione, R., 2016, Naturally occurring asbestos (NOA) in rock and soil and relation with human activities: The monitoring example: Italian Journal of Geosciences, v. 135, pp. 268-279.

Bloise, A., Ricchiuti, C., Giorno, E., Fuoco, I., Zumpano, P., Miriello, D., Apollaro, C., Crispini, A., De Rosa R., and Punturo, R., 2019, Assessment of naturally occurring asbestos in the area of Episcopia (Lucania, Southern Italy). Fibers, v. 7, Article number 45.

Bloise, A., Ricchiuti, C., Lanzafame, G. and Punturo, R., 2020, X-ray synchrotron microtomography: a new technique for characterizing chrysotile asbestos. Science of The Total Environment, v. 703, article number 135675.

Cattaneo, A., Somigliana, A., Gemmi, M., Bernabeo, F., Savoca, D., Cavallo, D.M., and Bertazzi, P.A., 2012, Airborne Concentrations of Chrysotile Asbestos in Serpentine Quarries and Stone Processing Facilities in Valmalenco, Italy. Annals of Occupational Hygiene, v. 56/6, pp. 671-683.

Cavallo, A., 2018, Serpentinitic waste materials from the dimension stone industry: Characterization, possible reuses and critical issues. Resources Policy, v. 59, pp. 17-23.

Cavallo, A., and Rimoldi, B., 2013, Chrysotile asbestos in serpentinite quarries: a case study in Valmalenco, Central Alps, Northern Italy. Environmental Science: Processes and Impacts, v. 15, pp. 1341-1350.

Chipera, S.J. and Bish, D.L., 2002, FULLPAT: a full-pattern quantitative analysis program for X-ray powder diffraction using measured and calculated patterns. Journal of Applied Crystallography, v. 35, pp. 744-749.

EEC, 2018, Directive 83/477/EEC of the European Communities Council on the protection of workers from the risks related to exposure to asbestos at work.

Gualtieri, A.F., 2012, Mineral fibre-based building materials and their health hazards, in: F. Pacheco-Torgal, S. Jalali, A. Fucic (Eds.), Toxicity of Building Materials, Woodhead, Cambridge, pp. 166-195.

Gualtieri, A.F., Bursi Gandolfi, N., Pollastri, S., Rinaldi, R., Sala, O., Martinelli, G., Bacci, T., Paoli, F., Viani, A. and Vigliaturo, R., 2018, Assessment of the potential hazard represented by natural raw materials containing mineral fibres-The case of the feldspar from Orani, Sardinia (Italy). Journal of Hazardous Materials, v. 350, pp. 76-87.

Gualtieri, A.F., Mossman, B.T. and Roggli, V.L., 2017, Towards a general model to predict the toxicity and pathogenicity of mineral fibres. In Gualtieri, A.F. (Eds.), Mineral Fibres: Crystal Chemistry, Chemical physical properties, Biological Interaction and Toxicity, EMU Notes in Mineralogy, 18. European Mineralogical Union and Mineralogical Society of Great Britain and Ireland, London, pp. 501-532.

Gualtieri, A.F., Pollastri, S., Bursi Gandolfi, N., Ronchetti, F., Albonico, C., Cavallo, A., Zanetti, G., Marini, P. and Sala, O., 2014, Determination of the concentration of asbestos minerals in highly contaminated mine tailings: An example from abandoned mine waste of Crètaz and Èmarese (Valle d'Aosta, Italy). American Mineralogist, v. 99, pp. 1233 1247.

IARC, 2012, Asbestos (chrysotile, amosite, crocidolite, tremolite, actinolite, and anthophyllite). IARC Monographs on the Evaluation Carcinogic Risks to Humans 100, pp 219-309. http://monographs.iarc.fr/ENG/Mohttp:// monographs.iarc.fr/ENG/Monographs/vol100C/mono100C.pdf

ISO, 2002, Ambient air - determination of numerical concentration of inorganic fibrous particles—scanning electron microscopy method 14966, International Standard Organization Geneva, Switzerland.

Italian Ministry of Health, 1994, Normative e metodologie tecniche di applicazione dell'art.6, comma 3, e dell'art.12, comma 2, della legge 27 marzo 1992, n.257, relativa alla cessazione dell'impiego dell'amianto, Gazzetta Ufficiale della Repubblica Italiana. n. 220 (suppl. ord. 129) and 288 (suppl. ord. 156), Istituto Poligrafico e Zecca dello Stato, Roma, Italy.

Italian Ministry of Health, 1996, Normative e metodologie tecniche per gli interventi di bonifica, ivi compresi quelli per rendere innocuo l'amianto, previsti dall'art. 5, comma 1, lettera f), della legge 27 marzo 1992, n. 257, 
recante: "Norme relative alla cessazione dell'impiego dell'amianto". Allegato 4: criteri relativi alla classificazione ed all'utilizzo delle "Pietre Verdi" in funzione del loro contenuto di amianto, Istituto Poligrafico e Zecca dello Stato, Roma, Italy.

Italian Ministry of Environment, 2006, Decreto Legislativo 3 aprile 2006, n. 152 Norme in materia ambientale. Gazzetta Ufficiale della Repubblica Italiana n.88 del 14-4-2006 (suppl. ord. 96), Istituto Poligrafico e Zecca dello Stato, Roma, Italy.

Münterer, O., and Hermann, J., 1996, The Val Malenco lower crust-mantle complex and its field relations (Italian Alps). Schweizerische Mineralogische und Petrographische Mitteilungen, v. 76, pp. 475-500.

Münterer, O., Hermann, J. and Trommsdorff, V., 2000. Cooling history and exhumation of lower-crustal granulite and upper mantle (Malenco, eastern Central Alps). Journal of Petrology, v. 41, pp. 175-200.

NIOSH (National Institute for Occupational Safety and Health), 1994, Asbestos by TEM: Method 7402, Issue 2, 15 August 1994.

NIOSH (National Institute for Occupational Safety and Health), 2011, Current intelligence bulletin 62. Asbestos Fibers and Other Elongate Mineral Particles: State of the Science and Roadmap for Research. Revised Edition (2011). https:/www.cdc.gov/niosh/docs/2011-159/pdfs/2011159.pdf
Petriglieri, J.R., Laporte-Magoni, C., Salvioli-Mariani, E., Tomatis M., Gazzano, E., Gunkel-Grillon, P., Turci, F., Cavallo, A., and Fubini, B., 2020, Identification and Preliminary Toxicological Assessment of a NonRegulated Mineral Fiber: Fibrous Antigorite from New Caledonia. Environmental and Engineering Geoscience, v. 26, pp. 89-97.

Rietveld, H.M., 1969, A profile refinement method for nuclear and magnetic structures. Journal of Applied Crystallography, v. 2, pp. 65-71.

Trommsdorff, V., and Connolly, J.A.D., 1996, The ultramafic contact aureole about the Bregaglia (Bergell) tonalite: isograds and a thermal model. Schweizerische Mineralogische und Petrographische Mitteilungen, v. 76, pp. 537-547.

Trommsdorff, V., Montrasio, A., Hermann, J., Müntener, O., Spillmann, P., and Gier, R., 2005, The geological map of Valmalenco. Schweizerische Mineralogische und Petrographische Mitteilungen, v. 85, pp. 1-13.

Ulmer, P., and Trommsdorff, V., 1995, Serpentine stability to mantle depths and subduction related magmatism. Science, v. 268, pp. 858-861.

WHO (World Health Organization), 1997, Determination of airborne fibre number concentrations (1997). http://apps.who.int/iris/bitstream/10665/ 41904/1/9241544961.pdf

Whitney, D., and Evans, B., 2010, Abbreviations for Names of RockForming Minerals. American Mineralogist, v. 95, pp. 185-187.

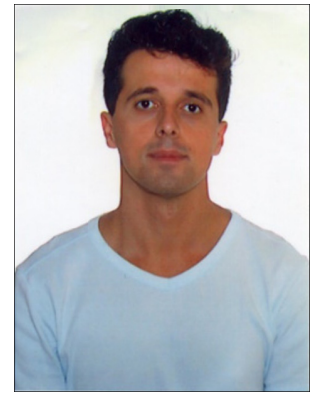

Alessandro Cavallo Graduated with honors in Geological Sciences at the University of Milan (Italy) in 2001. PhD in Earth Sciences at the University of Milan (Italy) in 2005. Grant researcher at the University of MilanBicocca (Italy), since 2005. From December 2008 researcher of the scientific sector GEO-09 "Mineral georesources and mineralogical-petrographical applications on environment and cultural heritage" at the University of Milan-Bicocca (Italy), Department of Earth and Environmental Sciences. Experiences in applied geology (cooperation with some applied geology offices). Explosive handling license (fire and electrical priming). Main skills: applied petrography, raw materials, quarries and mines, environmental geology, occupational health (asbestos and airborne mineral dust), ore geology, industrial minerals, crystallography, mineralogical, petrographical and technical characterization of dimension stones. Technical skills: optical microscopy, ore petrography, scanning electron microscopy (SEM), WDS and EDS microprobe analysis, X-ray powder diffraction (XRPD), infrared spectrometry (IR), phase contrast microscopy (PCM), whole rock XRF, ICP-OES, ICP-MS and NAA analysis. Main cooperation: INAIL-Contarp (Italian Worker's Compensation Authority - NOA project), University of Milan (COFIN 2002), Universidad Michoacana de San Nicolas de Hidalgo (Mexico), University of Turin (COFIN and OSMATER projects), Italy-Switzerland INTERREG (OSMATER project), Valtellina quarrier's association, University of ModenaReggio Emilia (PRIN 2012). Teaching: Basics of Ore geology and Industrial Minerals, Industrial and Environmental Mineralogy, Field Geology, Georesources and Ornamental Stones, Laboratory of Petrography. 